Instytut Archeologii

Uniwersytet Mikotaja Kopernika w Toruniu

ul. Szosa Bydgoska 44/48, 87-100 Toruń

dominika19973@onet.eu

Dominika Szczupak

\title{
KWESTIA LOKALIZACJI SIEDZIBY (KONWENTU) KOMTURÓW ZIEMI CHEŁMIŃSKIEJ W XIII-PIERWSZYCH DEKADACH XIV WIEKU
}

Zarys treści. W artykule podjęto próbę wskazania lokalizacji i scharakteryzowania formy architektonicznej siedzib komturów ziemi chełmińskiej. Rozważania na ten temat przeprowadzono na podstawie analizy źródeł historycznych, weryfikacji dotychczasowych poglądów oraz wyników badań archeologicznych.

Słowa kluczowe: komtur ziemi chełmińskiej, Starogród, Potterberg, Chełmno, Lipienek, archeologia, historia, zamek, warownia, zakon krzyżacki.

Jednym z ciekawszych problemów badawczych jest kwestia lokalizacji i wyglądu głównej siedziby (siedzib) komturów ziemi chełmińskiej w XIIIpierwszych dekadach XIV wieku. Precyzyjne wskazanie jej umiejscowienia przed 1285 rokiem nadal jednak sprawia duże trudności, co wynika z nikłych wzmianek w źródłach pisanych. Dotychczas najobszerniej temat ten został zaprezentowany przez Sławomira Jóźwiaka (1997, s. 140-155). Jednak od tego czasu badacze zajmujący się dziejami państwa krzyżackiego w Prusach nie podejmowali się zweryfikowania istniejących poglądów i przeprowadzenia dalszych badań. Tymczasem rozważania nad tym zagadnieniem należałoby przeprowadzić ponownie, chociażby ze względu na wyniki badań archeologicznych przeprowadzonych w latach 2016-2019 w ramach projektu pt. „Castra Terrae Culmensis - na rubieży chrześcijańskiego świata"', dzięki którym poszerzył się

\footnotetext{
${ }^{1}$ Projektem kierował dr hab. Marcin Wiewióra z Instytutu Archeologii Uniwersytetu Mikołaja Kopernika w Toruniu. Badania archeologiczne przeprowadzono w Papowie Biskupim, Zamku Bierzgłowskim, Starogrodzie, Unisławiu i Lipienku. Ich celem była próba odpowiedzi na pytania związane $\mathrm{z}$ istnieniem osadnictwa przedkrzyżackiego w miejscu przyszłych zamków, chronologią najstarszego osadnictwa krzyżackiego oraz układem przestrzennym zamków.
} 
stan wiedzy na temat zamków krzyżackich w ziemi chełmińskiej, co z kolei może być przydatne przy poszukiwaniu siedziby wspomnianego urzędnika.

Warto w tym miejscu wspomnieć o okolicznościach powołania urzędu komtura ziemi chełmińskiej oraz zakresie jego kompetencji. W okresie przedkomturskim, przed połową XIII wieku, zwierzchnictwo nad nowo pozyskanymi przez Zakon obszarami sprawowało dwóch urzędników krzyżackich określanych mianem zarządców - provisores (Jóźwiak 2012, s. 48). Zostali oni wymienieni w liście świadków pierwotnego przywileju chełmińskiego z 28 grudnia 1232 roku: Gerwinus in Culmine, Lodewicus in Quedin provisores (Przywilej chetmiński, s. 48-49; por. też Löwener 1998, s. 75; Dygo 2008a, s. 73; Jóźwiak 2012, s. 48). Należy zauważyć, że już w latach 30 . XIII wieku wśród zwierzchników zakonu krzyżackiego mógł pojawić się zamysł utworzenia w Prusach jednej lub dwóch prowincji (baliwatu) na wzór rozwiązania zastosowanego wcześniej na obszarze Niemiec, o czym może świadczyć fakt powołania wspomnianych wyżej urzędników (Jóźwiak 2012, s. 23, 222; Jähnig 2013, s. 281). Jednak do roku 1251 zamiar ten zarzucono, a zdobyte w Prusach tereny ostatecznie podporządkowano mistrzom krajowym (Jóźwiak 2012, s. 222).

Wymienionego w pierwotnym przywileju chełmińskim brata Gerwina (Berlewina), pełniącego funkcję prowizora, można uważać za poprzednika komtura ziemi chełmińskiej. Na związek pomiędzy tymi dwoma urzędami wskazuje pieczęć przywieszona do wystawionego w 1246 roku dokumentu biskupa chełmińskiego Heidenricha, w której otoku znajduje się napis: + S' CVLMENSIS PROV[ISOR]IS (Jóźwiak 2012, s. 50). Jak zauważył S. Jóźwiak, odpowiada on tytułowi prowizora z pierwotnego przywileju chełmińskiego (1232 rok) (Jóźwiak 2012, s. 50). Inna znana pieczęć komtura ziemi chełmińskiej została przywieszona do dokumentu z 1255 roku. Na jej otoku umieszczono napis: [+ S' COMMEND]ATOR IS DE CV[LMINE] (Oliński 1998, s. 12; Jóźwiak 2000, s. 116; 2012, s. 50). Obie pieczęcie wiązać należy z osobą Heinricha von Merbitz - pierwszego komtura ziemi chełmińskiej (por. niżej).

Początek kształtowania się struktur administracyjno-terytorialnych państwa krzyżackiego w Prusach przypada na rok $1246^{2}$. Miała tam wówczas miejsce wizyta ówczesnego wielkiego mistrza Heinricha von Hohenlohe, w trakcie której powołano dwa nowe urzędy: komtura elbląskiego ${ }^{3}$ oraz komtura ziemi chełmińskiej (Dygo 2008a, s. 73-74; Jóźwiak 2012, s. 51). Utworzenie tego ostatniego poprzedziło wydzielenie przez wspomnianego zwierzchnika Zakonu władztwa

\footnotetext{
${ }^{2} \mathrm{Na}$ podstawie analizy przesłanek odnoszących się do ziemi chełmińskiej i Kujaw, S. Jóźwiak uznał, że w okresie poprzedzającym powstanie pierwszych urzędów komturskich określone terytoria zarządzane były przez braci-rycerzy działających z upoważnienia prowizora chełmińskiego. Natomiast mniejsze dobra mogły być pod pieczą osób świeckich - poddanych krzyżackich (Jóźwiak 2012, s. 51).

${ }^{3}$ Pierwszy komtur elbląski, Aleksander, pojawił się w liście świadków dokumentu lokacyjnego Elbląga z 10 kwietnia 1246 roku (Dygo 2008a, s. 74; Jóźwiak 2012, s. 51).
} 
terytorialnego dla biskupów chełmińskich (Jóźwiak 2012, s. 45). Nowo powołanemu urzędnikowi krzyżackiemu przekazano w zarząd obszary, które na przełomie lat 30. i 40. XIV wieku weszły w skład wójtostwa lipieneckiego, komturstwa brodnickiego i najprawdopodobniej wójtostwa bratiańskiego. Ponadto między rokiem 1309 a 1311 zasięg jego władzy terytorialnej czasowo poszerzył się o południowe tereny Pomorza Gdańskiego (Jóźwiak 2012, s. 46, 119).

$\mathrm{Z}$ analizy treści dokumentów (m.in. pierwotnego i odnowionego przywileju chełmińskiego z 1232 i 1251 roku) oraz szczątkowej korespondencji wymienianej między urzędnikami krzyżackimi wynika, że do obowiązków komtura ziemi chełmińskiej należało: sprawowanie sądownictwa nad rycerstwem tego obszaru, przeprowadzanie wizytacji zarządzanego przez niego terytorium oraz egzekwowanie obowiązku wojskowego ze strony posiadaczy dóbr służebnych (Jóźwiak 2012, s. 46-48). Urzędnik ten przejmował również tymczasowo zarząd nad niektórymi komturstwami: grudziądzkim (lata 1299-1309), rogozińskim (przed 1306 rokiem), starogrodzkim (lata 1310-1320), pokrzywieńskim (lata 1320-1325) oraz nad obszarem po zlikwidowanym po 1316 roku komturstwie wieldządzkim. Od drugiej dekady XIV wieku zostały mu dodatkowo podporządkowane dwa konwenty: lipienecki - z komturem domowym i brodnicki z wójtem ziemi chełmińskiej i tamtejszym komturem domowym (Jóźwiak 2012, s. $47,71,152)$.

Pierwszym poświadczonym przez źródła pisane komturem ziemi chełmińskiej był Heinrich von Merbitz, który sprawował ten urząd zapewne od roku 1246 (Dorna 2004, s. 375; Dygo 2008a, s. 73). Część badaczy uznała, że komturstwo to najprawdopodobniej zastąpiło wcześniejsze prowizorstwo w Chełmnie, mogące mieć charakter (niedoszłego do skutku) baliwatu (Dygo 2008a, s. 73; Jóźwiak 2012, s. 49). Powyższe spostrzeżenie wynikało między innymi z analizy i porównania listy świadków pierwszego przywileju chełmińskiego z 1232 roku i jego odnowionej wersji z roku 1251 - w tym ostatnim tytuł prowizora został zastąpiony tytułem komtura ziemi chełmińskiej (Löwener 1998, s. 77, 171-172; Jóźwiak 2012, s. 49).

Heinrich von Merbitz był komturem ziemi chełmińskiej do roku 1259 (Dorna 2004, s. 375; Dygo 2008a, s. 96). Jednak od 1260 roku, jak zauważył Marian Dygo, zaczęły pojawiać się jakieś perturbacje w obsadzie tego urzędu. Niezaprzeczalnie wiązało się to $\mathrm{z}$ niestabilną sytuacją Zakonu, do której w znacznej mierze przyczyniło się drugie powstanie pruskie z lat 1260-1274 (Dygo 2008b, s. 87, 96). W tym czasie komturstwo ziemi chełmińskiej obsadzane było trzykrotnie, przy czym Bertold von Nordhausen miał sprawować ten urząd dwukrotnie: w latach 1260/1264-1268 oraz w latach 1274-1276 (Dorna 2004, s. 375; Jähnig 2013, s. 291). Po roku 1276 komturem ziemi chełmińskiej został Herman von

${ }^{4}$ W międzyczasie, w latach 1268-1270, urząd komtura ziemi chełmińskiej sprawował Konrad von Thierberg Starszy (Dorna 2004, s. 375). 
Schönburg (Dorna 2004, s. 375; Dygo 2008b, s. 96; Jähnig 2013, s. 291). W przeciwieństwie do swojego poprzednika ${ }^{5}$, posiadał on większe doświadczenie, które zdobył na innych stanowiskach - komturów dzierzgońskiego i zantyrskiego (Dorna 2004, s. 234-235; Dygo 2008b, s. 96). W kolejnych latach urząd ten sprawowali: Konrad Stange (1289 rok), Jan von Alvensleben (lata 1291-1296), Konrad Sack (lata 1296-1298), Günther von Schwarzburg (lata 1299-1309), Dietrich von Lichtenhain (lata 1310-1313), Heinrich von Gera (lata 1315-1319), Otto von Lutterberg (lata 1320-1333), Konrad Kesselhut (lata 1333-1334) oraz Heinrich Reuß von Plauen (1335 rok) (Jóźwiak 1998, s. 23-26; Dorna 2004, s. 375-376; Dygo 2008b, s. 96; Jähnig 2013, s. 291).

Komturstwo ziemi chełmińskiej funkcjonowało przynajmniej do 1335 roku, po czym zostało rozwiązane (Jóźwiak 2012, s. 134). Następstwem jego likwidacji było powołanie dwóch nowych jednostek terytorialnej administracji zakonnej, podległych bezpośrednio władzom centralnym w Malborku: wójtostwa nowomiejskiego (bratiańskiego) (w 1343 roku), wójtostwa lipieneckiego (w 1340 roku) oraz komturstwa brodnickiego (w 1337 roku). Wójtostwo lipieneckie zostało utworzone po likwidacji tamtejszego komturstwa w 1340 roku i powierzone byłemu wójtowi ziemi chełmińskiej, który do roku 1340 najprawdopodobniej rezydował w Brodnicy (Jóźwiak 2008, s. 133; 2012, s. 134-135, 138). W tym miejscu należy zauważyć, że wspomniany wójt ziemi chełmińskiej po 1313 roku przejął, wraz z komturem domowym w Lipienku, kompetencje kompana komtura ziemi chełmińskiej ${ }^{6}$. Należało do nich między innymi dokonywanie pomiarów dóbr w obrębie wymienionej jednostki administracyjnej czy też dowodzenie armią rekrutującą się ze świeckich lenników Zakonu z tego terytorium (Jóźwiak 2012, s. 150). Bezpośrednim następstwem likwidacji komturstwa ziemi chełmińskiej było też czasowe podporządkowanie (do 1340 roku) zachodniej części byłego obszaru tej jednostki administracji terytorialnej zarządcy z Lipienka, natomiast południowo-wschodniej części - powołanemu w 1337 roku komturowi brodnickiemu (Jóźwiak 2012, s. 134).

Rozważania na temat lokalizacji siedziby komtura ziemi chełmińskiej przed 1285 rokiem należy zacząć od Starogrodu. Pierwsza warownia krzyżacka (około $6 \mathrm{~km}$ na południowy zachód od Chełmna), powstała tam z inicjatywy Hermana Balka w 1232 roku; lokalizuje się ją około $6 \mathrm{~km}$ na południowy zachód od Chełma (Piotr z Dusburga, s. 49; Wiewióra 2016, s. 200). W tym samym czasie

\footnotetext{
${ }^{5}$ Jak podaje krzyżacki kronikarz Piotr z Dusburga, Bertold von Nordhausen, nie posiadał odpowiednich umiejętności dowódczych, i dlatego został przez przełożonych zdjęty z urzędu komtura ziemi chełmińskiej (Piotr z Dusburga, s. 150; por. też Dorna 2004, s. 118-120; Jóźwiak 2012, s. 47).

${ }^{6}$ Kompan komtura ziemi chełmińskiej po raz ostatni pojawił się w dokumencie z 22 lipca 1313 roku (Jóźwiak 2012, s. 150).
} 
w sąsiedztwie lokowano Chełmno ${ }^{7}$ - obok Torunia najstarsze miasto na ziemi chełmińskiej, które z czasem zostało jednak translokowane ${ }^{8}$ (Jóźwiak 1996; Chudziak 2014, s. 59).

Biorąc za punkt wyjścia fakt, że w tym najwcześniejszym okresie to właśnie w Starogrodzie rezydował krzyżacki provisor chełmiński wzmiankowany w dokumencie z 1232 roku, należałoby bliżej przyjrzeć się pozostałościom po tym obiekcie. Warownię wzniesiono w konstrukcji drewniano-ziemnej, co potwierdziły badania archeologiczne prowadzone w 2017 roku$^{9}$ (Wasik 2017a). Jej relikty zarejestrowano w trzech wykopach, w jednym z nich (wykop 3) na izolacyjnej warstwie zielonkawej gliny zalegały cienkie, nieokorowane deski (warstwa 35), a także czytelny był negatyw posłupowy (Wasik 2017a; Wasik, Cackowski 2017). Chronologię powstania najstarszego drewniano-ziemnego założenia, na podstawie analizy materiału ceramicznego, datowano na drugą ćwierć XIII wieku (Wasik 2017a). Trudno wątpić w to, że w latach 40. XIII wieku warownia w Starogrodzie uzyskała wysoką rangę. Przyczyniło się do tego przede wszystkim zdeponowanie tam jednej z najważniejszych relikwii w państwie krzyżackim w Prusach - głowy św. Barbary zdobytej w Sartowicach w 1242 roku (Piotr z Dusburga, s. 64-65; Torbus 2014, s. 70; Wasik 2016a, s. 268; Jóźwiak, Trupinda 2020, s. 143). Co równie istotne, w 1243 roku skutecznie oparła się ona, obok Torunia i Radzynia, atakowi Prusów (Piotr z Dusburga, s. 63; Dygo 2008a, s. 69; Wasik 2016a, s. 268). Były zatem przesłanki do podjęcia decyzji o rozpoczęciu budowy zamku murowanego (Wasik 2016a, s. 268). Czy powołanie urzędu komtura ziemi chełmińskiej w 1246 roku mogło mieć również wpływ na zainicjowanie przekształcania warowni drewniano-ziemnej w założenie murowane? W literaturze przedmiotu można spotkać się jedynie z przypuszczeniami,

\footnotetext{
${ }^{7}$ Pozostałości pierwszego lokacyjnego Chełmna z 1232 roku odkryto w trakcie badań archeologicznych prowadzonych w 2018 roku pod kierownictwem Bogusza Wasika na obszarze II przedzamcza zamku starogrodzkiego (Sprawozdanie z badań 2018).

${ }^{8}$ Przedlokacyjne Chełmno znajdowało się na obszarze dzisiejszej wsi Kałdus (pow. Chełmno), przy Górze św. Wawrzyńca. Badania archeologiczne, prowadzone w latach 1996-2015 przez Instytut Archeologii UMK w Toruniu wykazały, że był to rozległy kompleks osadniczy składający się z grodu, osady rzemieślniczo-handlowej oraz cmentarzyska (Chudziak, Bojarski 2015, s. 85). Rezultaty tych badań zostały przedstawione między innymi w serii „Mons Sancti Laurentii”. Pierwsze lokacyjne Chełmno znajdowało się w sąsiedztwie zamku starogrodzkiego; najprawdopodobniej w 1247 roku zostało translokowane na obszar Rybaków (obecnie dzielnica Chełmna), do czego z pewnością przyczyniło się jego spalenie w trakcie walk z księciem Świętopełkiem w 1244 roku (Jóźwiak 1997, s. 26-27; Chudziak, Bojarski 2015, s. 86; Wasik 2016a, s. 268). Jednak ze względu na zagrożenie wylewami Wisły, konieczne było przeniesienie miasta na pobliskie wzgórza, co nastąpiło między 1251 a 1253 rokiem. Wówczas znalazło się ono w obecnym miejscu (Jóźwiak 1996, s. 91-94; Czaja 2008, s. 179; Jóźwiak, Trupinda 2020, s. 142).

${ }^{9}$ Badania prowadzone pod kierownictwem Bogusza Wasika realizowane były w ramach projektu pt. „Castra Terrae Culmensis - na rubieży chrześcijańskiego świata”.
} 
że siedziba tego krzyżackiego urzędnika znajdowała się właśnie w Starogrodzie (Steinbrecht 1888, s. 8, 19; Jóźwiak 1997, s. 19-21; Torbus 2014, s. 290). Należy jednak zwrócić uwagę na zbieżność daty powołania urzędu komtura ziemi chełmińskiej (1246 rok) z powstaniem sąsiadującej z Chełmnem (Starogrodem) warowni Potterberg (około 1246/1247), o której pisał w swojej kronice Piotr z Dusburga (Piotr z Dusburga, s. 76-77; por. też Jóźwiak 1997, s. 144). Może już wówczas nastąpiło przeniesienie siedziby tego urzędnika z Chełmna (Starogrodu) do Potterbergu. Zwłaszcza, że przynajmniej od 1251 roku w Starogrodzie rezydował tamtejszy komtur, a nie komtur ziemi chełmińskiej (Dygo 2008a, s. 74; Jóźwiak 2012, s. 55). Mimo powyższych przesłanek wskazujących na umiejscowienie siedziby komtura ziemi chełmińskiej przynajmniej od 1246/1247 roku w warowni Potterberg, autorka bierze również pod uwagę ewentualność rezydowania tego urzędnika w Starogrodzie w latach 1246-1285. Ze względu na brak bezpośrednich wzmianek na ten temat w średniowiecznych źródłach pisanych można jedynie domyślać się dlaczego komtur ziemi chełmińskiej miał rezydować właśnie tam. Prawdopodobnie w Starogrodzie rezydował bowiem wzmiankowany w pierwotnym przywileju chełmińskim zarządca (provisor), którego można uważać za poprzednika komtura ziemi chełmińskiej (Jóźwiak 2012, s. 50,54). Nie bez znaczenia było również przechowywanie tam jednej z najważniejszych relikwii, co niewątpliwie podkreślało i wzmacniało wówczas pozycję tego urzędnika. Co prawda później, w latach 1310-1320, komtur ziemi chełmińskiej przejął czasowe zwierzchnictwo nad obszarem podległym komturstwu starogrodzkiemu, jednak wątpliwym jest, aby w tym czasie rezydował on w Starogrodzie, skoro miał wówczas swoją siedzibę w Lipienku (por. niżej; Jóźwiak 2012, s. 47).

Biorąc pod uwagę powyższe spostrzeżenia, można przypuszczać, że rozpoczęcie budowy murowanego założenia w Starogrodzie miało miejsce już u schyłku czwartej dekady XIII wieku. Za tak wczesną chronologią może przemawiać nie tylko nieregularność układu przestrzennego zamku, ale również podobieństwo jego formy do warowni w Toruniu i Bałdze, a także moneta datowana na lata 1237-1248, którą pozyskano w trakcie badań archeologicznych (Wasik 2017a; Wasik, Cackowski 2017). Ponadto z analizy dokumentów wystawionych w starogrodzkiej warowni w 1254 i 1255 wynika, że w tym czasie część drewniano-ziemnych umocnień mogła być już zastąpiona konstrukcjami murowanymi, o czym świadczy pojawiający się w ówczesnych wystawianych tam dokumentach łaciński rzeczownik castrum, co na obszarze państwa krzyżackiego w Prusach było rzadko stosowane (Jóźwiak, Trupinda 2020, s. 142).

Przez długi czas badacze nie potrafili odtworzyć formy architektonicznej zamku w Starogrodzie, na co miał wpływ brak zachowanych reliktów zabudowy na powierzchni terenu oraz nieefektywne badania archeologiczne z lat 1963-1964 (Wasik 2017b). Posługiwano się więc niemal wyłącznie nowożytnymi opisami 


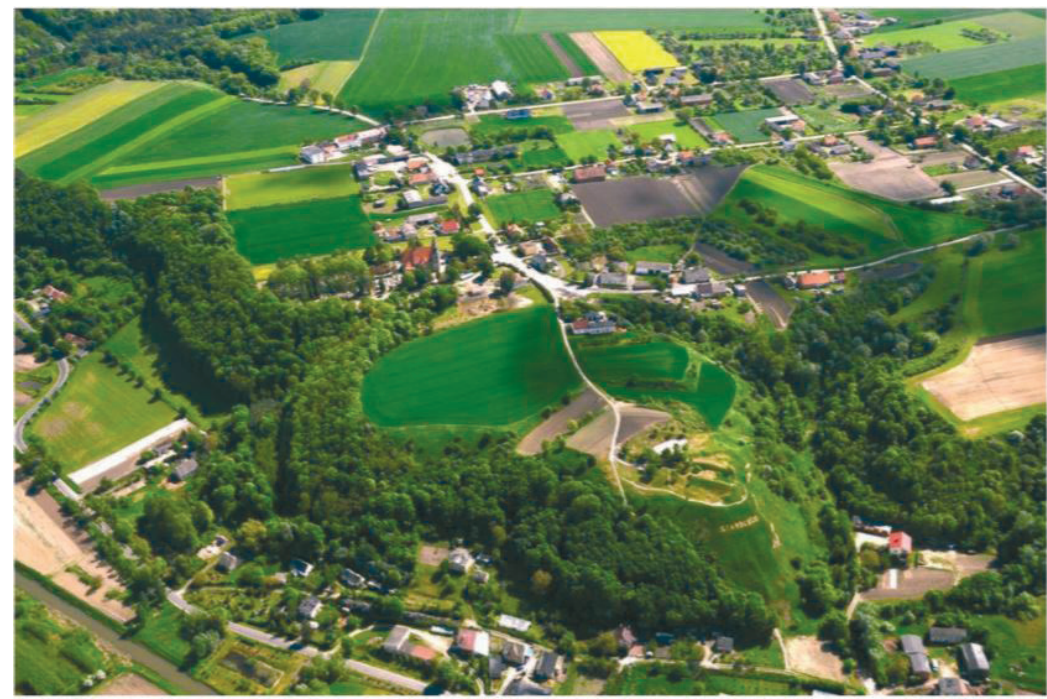

Ryc. 1. Starogród, pow. Chełmno. Widok na obszar dawnego założenia zamkowego (wg Chudziak 2014)

Fig. 1. Starogród, Chelmno district. View of the area of the former castle complex (after Chudziak 2014)

lustratorów oraz szkicem Johanna Giese, który opublikował Conrad Steinbrecht (Steinbrecht 1888, s. 19: Abb. 23; Wasik 2016a, s. 268-271). Dopiero wyniki wspomnianych już wcześniej prac archeologicznych z 2017 roku umożliwiły podjęcie kolejnej, bardziej efektywnej próby odtworzenia układu przestrzennego tej warowni.

Założenie w Starogrodzie, składające się z zamku wysokiego, przedzamcza I oraz przedzamcza II, ulokowano na stromym cyplu wysoczyzny morenowej (ryc. 1), co sprawia, że można zaliczyć je do zamków typu wyżynnego (Wasik 2016a, s. 268-271) ${ }^{10}$. Swoją pełną formę architektoniczną obiekt uzyskał w trakcie prac budowlanych prowadzonych u schyłku XIII i na początku XIV wieku (ryc. 2) (Wasik 2017a). Zatem od końca lat 40. XIII wieku do roku 1285, czyli w okresie kiedy Starogród mógł pełnić funkcję siedziby komtura ziemi chełmińskiej, w obrębie zamku wysokiego obok zabudowy murowanej najprawdopodobniej znajdowały się jeszcze budynki drewniane. Z pewnością warownia posiadała już murowane skrzydło południowo-zachodnie, które na pierwszej kondygnacji mieściło kaplicę (Wasik 2017a). Na przykładzie innych zamków z ziemi chełmińskiej, między innymi Torunia i Pokrzywna, można sądzić, że w trakcie prze-

${ }^{10}$ Podział zamków krzyżackich w ziemi chełmińskiej, uwzględniający ich topografię i lokalizację został opracowany przez autorkę niniejszego artykułu na podstawie kryteriów zaproponowanych przez Bohdana Guerquin i przedstawiony w jej pracy licencjackiej (Szczupak 2019). 


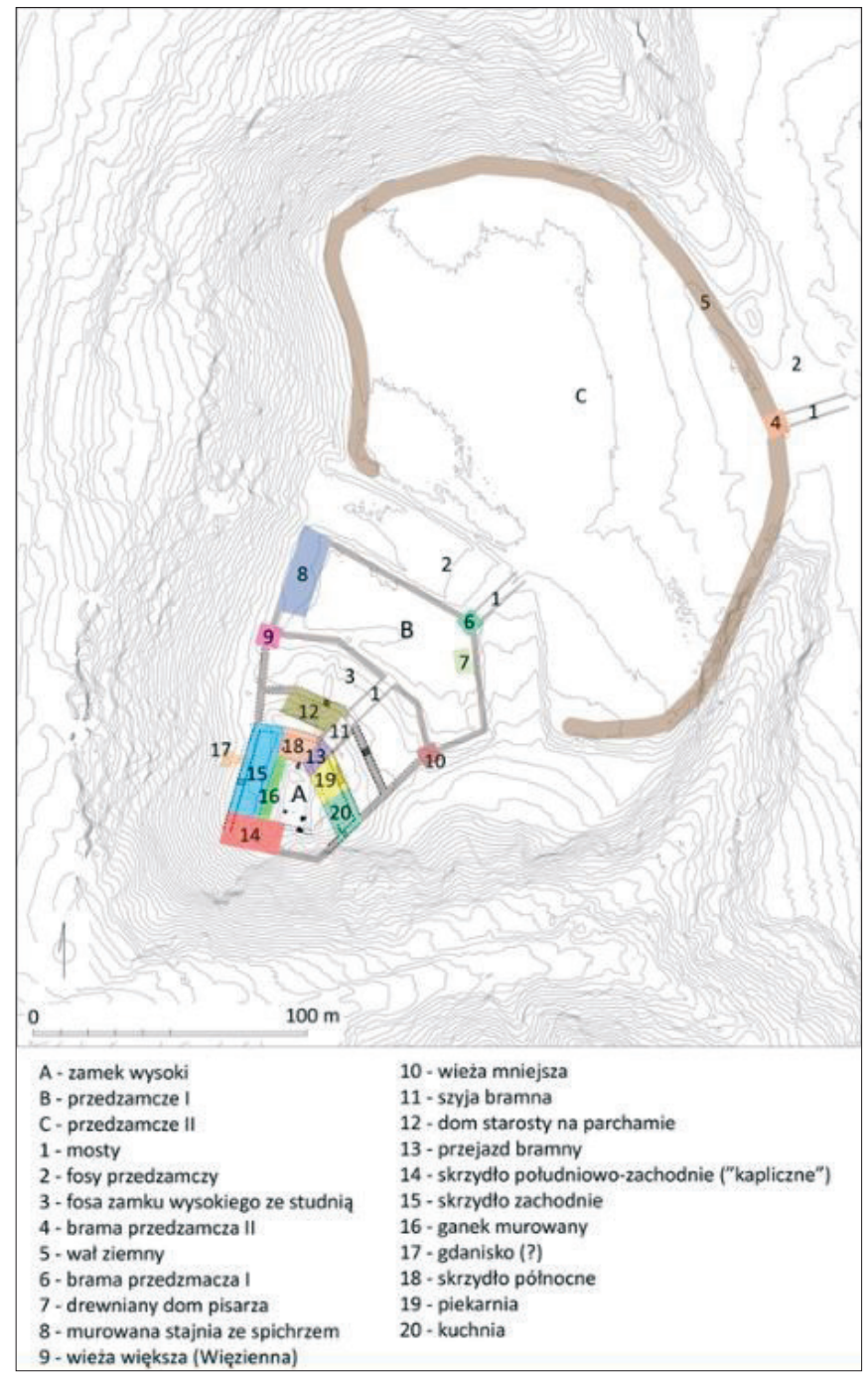

Ryc. 2. Starogród, pow. Chełmno. Rekonstrukcja przestrzeni zamkowej w połowie XVII wieku na podstawie nowożytnych inwentarzy (oprac. B. Wasik)

Fig. 2. Starogród, Chelmno district. Reconstruction of the castle space in the mid-1 $17^{\text {th }}$ century based on the post-medieval inventories (edited by B. Wasik)

kształcania warowni drewniano-ziemnych w założenia murowane jako pierwsze wzniesiono skrzydło mieszczące później kaplicę zamkową (Wasik 2016a, s. 316). Praktyka ta wynikała $\mathrm{z}$ regulacji zawartych w zakonnych źródłach normatywnych, zgodnie z którymi księża i bracia powinni uczęszczać na oficjum i godziny kanoniczne do świątyni (Jóźwiak, Trupinda 2012, s. 39-40). Było to więc najważniejsze pomieszczenie na zamku krzyżackim, zatem nie można mieć wątpliwości, że w przypadku Starogrodu skrzydło kapliczne zostało wybudowane 
jako pierwsze. Niewykluczone, że do 1285 roku powstała również zachodnia część obwodu zamkowego, w której na pierwszej kondygnacji znajdować się miał refektarz (Wasik 2017a). Nie ma pewności, czy wzdłuż obu wspomnianych skrzydeł przebiegał już wówczas jakiś wewnętrzny ganek. Co prawda jego istnienie potwierdzają późniejsze wzmianki w wizytacjach z lat 1442-1446 oraz wyniki badań archeologicznych, ale nadal trudno precyzyjnie ustalić czas powstania tej części założenia zamkowego (Wasik 2017a; Jóźwiak, Trupinda 2020, s. 144-145). Pomieszczenia o charakterze gospodarczym (kuchnia, browar i piekarnia) przypuszczalnie znajdowały się wówczas jeszcze w budynkach drewnianych, gdyż zabudowa murowana w części wschodniej, w której później je umieszczono, powstała dopiero około połowy XIV wieku (Wasik 2017a).

Od północy zamek wysoki otoczony był fosą, z czasem obmurowaną, a także parchamem; przez nie od strony północno-wschodniej znajdował się wjazd do zamku wysokiego (Wasik 2017a, s. 54). W kierunku północno-wschodnim od niego rozciągało się przedzamcze I ze stajniami komtura, oborą, kuźnią oraz łaźnią (Wasik 2016a, s. 271; 2017a). Z kolei dalej na północny wschód położone było, otoczone wałem ziemnym, przedzamcze II, w obrębie którego odkryto pozostałości pierwotnego miasta Chełmna lokowanego w 1232 roku (por. przypis 7).

Znacznie mniej informacji odnosi się do krzyżackiej warowni Potterberg (obecnie wieś Kałdus - około $5 \mathrm{~km}$ na południowy zachód od Chełmna). Od schyłku lat 40 . do początku lat 80 . XIII wieku mogła ona stanowić siedzibę komtura ziemi chełmińskiej (Jóźwiak, Trupinda 2020, s. 142). Jednak podobnie jak w przypadku Starogrodu, są to jedynie przypuszczenia. Należy tu przede wszystkim wziąć pod uwagę przekaz krzyżackiego kronikarza Piotra z Dusburga, który podaje: „Brat i mistrz Poppo [von Osternah, wówczas pruski mistrz krajowy - D. Sz.] [...] wybudował na wzgórzu znajdującym się pomiędzy obecnym miastem Chełmnem a Starogrodem zamek [...] i osadził w nim 12 braci wraz z wieloma zbrojnymi" (Piotr z Dusburga, s. 76-77). W ten sposób Krzyżacy zapobiegli wzniesieniu jakichkolwiek umocnień na prawym brzegu Wisły przez księcia Świętopełka, który zdążył już wybudować gród w Świeciu na jej lewym brzegu (Piotr z Dusburga, s. 76-77). Blokował on żeglugę krzyżacką na rzece, stanowiacej wówczas ważny szlak komunikacyjny (Dygo 2008a, s. 69-70; Wasik 2016b, s. 32). Warownia Potterberg musiałaby zatem powstać bezpośrednio po 1244 roku, w trakcie walk Zakonu z księciem Świętopełkiem; w literaturze przedmiotu można spotkać się z datowaniem jej na lata 1253-1257 (Poliński 2005, s. 190; Dygo 2008a, s. 69-70; Wasik 2016b, s. 234). Taka chronologia wydaje się jednak nieco późna, bardziej prawdopodobny jest rok 1246/1247, zaproponowany przez S. Jóźwiaka (1997, s. 144). Przypuszcza się, że na miejsce pod budowę wybrano Górę św. Wawrzyńca (ryc. 3), za czym przemawiałyby nie tylko naturalne walory obronne oraz bliskość rzeki, ale również możliwość zablokowania drogi do pierwotnego Chełmna (Starogrodu), które spłonęło w 1244 roku (Jóźwiak 1997, s. 143-144; 


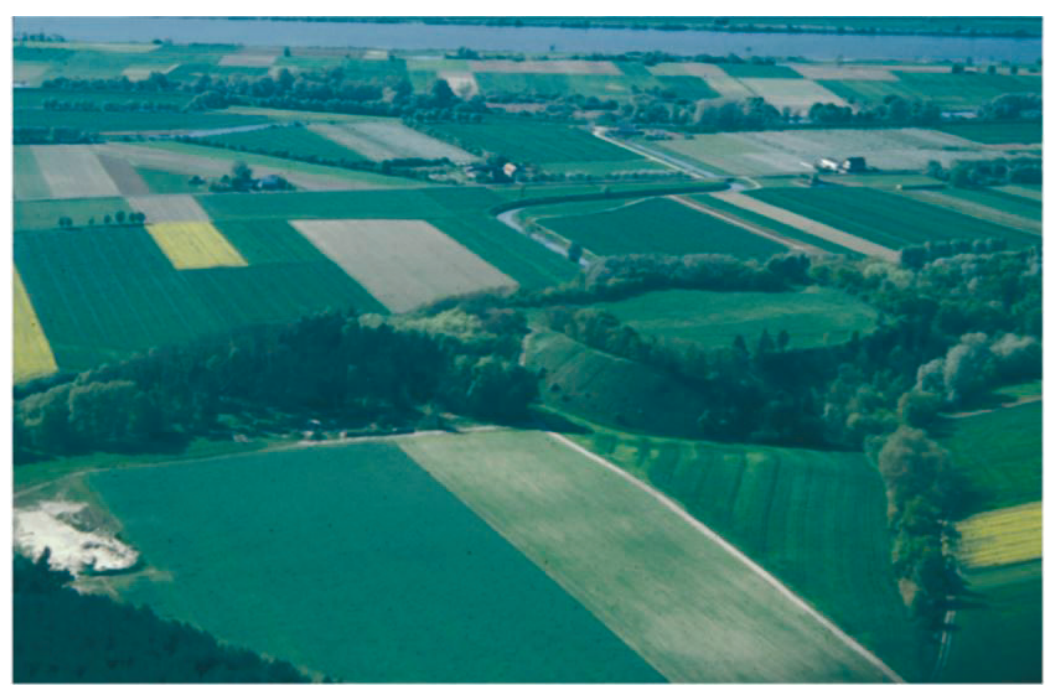

Ryc. 3. Kałdus, pow. Chełmno. Widok na Górę św. Wawrzyńca (wg Chudziak 2014) Fig. 3. Kałdus, Chełmno district. View of St Lawrence Mount (after Chudziak 2014)

Dygo 2008a, s. 69). Na taką lokalizacją warowni może także wskazywać jej nazwa - Potterberg, wywodząca się od Hugona Butyra, który w latach 40. XII wieku sprawował urząd kasztelana chełmińskiego, a co za tym idzie jego siedziba znajdowała się w Chełmnie (Kałdusie). Miał on rozbudować i umocnić tamtejszy gród, który z czasem przyjął nazwę Buttirberg (Powierski 1972, s. 22-24, 26). Kasztelan chełmiński został również wspomniany w kronice Piotra z Dusburga: „Od dawna przeciwko Prusom [...] prowadzone były liczne wojny [...] przez Hugona zwanego Potyre" (Piotr z Dusburga, s. 26). Nazwa wzgórza między Chełmnem a Starogrodem wywodziła się zatem od Hugona Butyra/Potyre i funkcjonowała jeszcze w XIII wieku, o czym może świadczyć niniejszy zapis z kroniki Dusburga: „Brat i mistrz Poppo [...] wybudował zamek, który od nazwy wzgórza nazwał Potterberg [...]" (Piotr z Dusburga, s. 77).

Jeśli chodzi o zlokalizowaną tam późniejszą siedzibę komtura ziemi chełmińskiej dostrzega się - jak już wyżej wspomniano - zbieżność daty powołania tego urzędu (1246 rok) z powstaniem warowni Potterberg (około 1246/1247) (Jóźwiak 1997, s. 144). Być może więc warownię tę wzniesiono z myślą o siedzibie dla wymienionego urzędnika. Przemawiałaby za tym również liczba przebywających w niej rycerzy zakonnych, dość pokaźna jak na ówczesne warunki ${ }^{11}$ (Piotr

${ }^{11}$ Dla porównania można tu przywołać liczebność niektórych konwentów krzyżackich w ziemi chełmińskiej u schyłku XIV i w pierwszej połowie XV wieku. Konwenty bierzgłowski i pokrzywieński liczyły wówczas około 10 braci-rycerzy, toruński - od 15 do 17, grudziądzki, golubski i radzyński - poniżej 10 (Tandecki 2008, s. 407; Jóźwiak, Trupinda 2012, s. 53, 56). Problematykę wielkości krzyżackich konwentów w państwie krzyżackim w Prusach poruszył także S. Jóźwiak (2007). 
z Dusburga, s. 76-77). Istnieje jeszcze jedna ewentualność - komtur ziemi chełmińskiej mógł rezydować w warowni Potterberg od 1251 roku, kiedy to powołano urząd komtura starogrodzkiego (Piotr z Dusburga, s. 74; por. też Jóźwiak 2012, s. 55). Należałoby jednak przyjąć, że do tego czasu rezydował on w Starogrodzie. Niestety, żadne źródła pisane nie pozwalają na potwierdzenie tych domysłów. Gdyby rzeczywiście Potterberg ustanowiono siedzibą komtura ziemi chełmińskiej, to wówczas w miejscu drewniano-ziemnego założenia powstałby zamek murowany. Jednak w trakcie badań archeologicznych prowadzonych w latach 60 . i 70. XX wieku nie odkryto żadnych murowanych reliktów, które mogłyby świadczyć o takich działaniach budowlanych ${ }^{12}$. Odsłonięto wówczas jedynie pozostałości wału ziemnego z trzema rzędami palisady w jego górnej części, które można by wiązać z krzyżacką warownią Potterberg. Wbite ciasno pale skierowane były skośnie na zewnątrz wału, w ten sposób odcinając krzyżackie założenie obronne od pozostałej części starego grodu (Kola, Matuszewska-Kola 1971, s. 171; Wasik 2016b, s. 240). Natomiast w południowo-wschodniej części Krzyżacy zaadaptowali do celów obronnych stary, ale nadal okazały wał (Wasik 2016b, s. 240). Na podstawie analizy nawarstwień i fragmentów naczyń ceramicznych chronologię obiektu ustalono na drugą połowę XIII wieku (Poliński 2005, s. 190).

Jak pisał krzyżacki kronikarz Piotr z Dusburga - ,[...] bracia w roku Pańskim 1283 przenieśli z ziemi chełmińskiej zamek Potterberg i z jego budulca wznieśli zamek Gniew w tym miejscu nad Wisłą, gdzie stoi teraz na cześć i chwałę Jezusa Chrystusa" (Piotr z Dusburga, s. 160). Z przytoczonego zapisu wynika, że Krzyżacy rozebrali wówczas warownię, a pozyskany budulec (z pewnością w postaci drewna i kamieni) spławiono Wisłą i wykorzystano do wzniesienia nowego założenia obronnego - zamku komturskiego w Gniewie (Piotr z Dusburga 2004, s. 160; por. też Poliński 2005, s. 190; Torbus 2014, s. 171).

W tym miejscu należałoby zwrócić uwagę na kilka istotnych kwestii, wiążących się z krótkim okresem istnienia urzędu komturskiego w translokowanym mieście Chełmnie. Po raz pierwszy tamtejszy komtur (Gibbehardus czum nuwen Culmen) pojawił się obok komtura starogrodzkiego (Johan von Bydowen czum alden Culmen) w liście świadków odnowionego przywileju dla rycerstwa polskiego w ziemi chełmińskiej, wystawionego 17 listopada 1278 roku przez wicemistrza krajowego Konrada von Thierberg (Jóźwiak 1997, s. 25; 2012, s. 59). Niektórzy badacze sugerują, że przed 1285 rokiem w translokowanym Chełmnie rezydował komtur ziemi chełmińskiej (Steinbrecht 1888, s. 6, 15; Mroczko 1974, s. 287; Torbus 2014, s. 290). W każdym razie ze źródeł pisanych wynika, że przed rokiem 1278 Krzyżacy powołali do istnienia urząd komtura rezydującego w Chełmnie, który jednak zniesiono przed 1285 rokiem (Jóźwiak 1997, s. 24-34; Jóźwiak, Trupinda 2020, s. 142). Interesujący jest fakt, że data

${ }^{12}$ Badania archeologiczne prowadzone były pod kierownictwem Wiesławy MatuszewskiejKoli i Andrzeja Koli. 
likwidacji wspomnianego urzędu jest zbieżna z pojawieniem się siedziby komturów ziemi chełmińskiej w Lipienku (por. niżej). Czy można zatem sądzić, że między 1278 a 1285 rokiem w Chełmnie rezydował obok tamtejszego komtura również komtur ziemi chełmińskiej? Ze względu na brak innych wzmianek w źródłach pisanych trudno udzielić na to pytanie jednoznacznej odpowiedzi. Niewiele można również powiedzieć na temat tamtejszej warowni. Badacze nie dysponują bowiem żadnymi źródłami pisanymi ani wynikami badań archeologicznych, które mogłyby pomóc w ustaleniu chronologii powstania obiektu, poszczególnych faz jego budowy oraz ostatecznej formy architektonicznej, a co za tym idzie, nieznana jest również jego lokalizacja. W literaturze przedmiotu można spotkać teorię, według której zamek znajdował się w północno-zachodniej części miasta-obecnie na obszarze zespołu klasztornego Sióstr Miłosierdzia. Jego pozostałością byłaby tzw. wieża Mestwina, która w XIV wieku miała zostać włączona w skład kompleksu klasztoru cysterek ${ }^{13}$ (ryc. 4) (Domasłowski 1983, s. 19; Antkowiak, Lamparski 1999, s. 28-31). Włodzimierz Antkowiak i Piotr Lamparski podają, że warownia miała powstać tuż po wystawieniu pierwotnego przywileju chełmińskiego. Założyli jednak, że lokacyjne Chełmno już w 1232 roku znajdowało się w obecnym miejscu, co jest sprzeczne z dotychczasowym stanem badań i należy odnieść to do położonego $6 \mathrm{~km}$ na południowy zachód od Chełmna Starogrodu (Jóźwiak 1996; Antkowiak, Lamparski 1999, s. 28-31; Chudziak 2014, s. 59; Chudziak, Bojarski 2015, s. 86). Warownia krzyżacka na obszarze dzisiejszego Chełmna mogłaby zatem powstać najwcześniej w latach 50. XIII wieku, po trzeciej translokacji miasta, która miała miejsce między 1251 a 1253 rokiem lub na przełomie lat 70. i 80. XIII wieku, co wynikałoby z faktu powołania urzędu komtura chełmińskiego w 1278 roku (Jóźwiak 1997, s. 24-34; Jóźwiak, Trupinda 2020, s. 142). Warto jednak wspomnieć, że w odnowionym przywileju chełmińskim (1251 rok) Krzyżacy zobowiązywali się do nienabywania parcel w Chełmnie (Przywilej chełmiński). Ze względu na brak wzmianek w źródłach pisanych oraz jakichkolwiek odkryć archeologicznych trudno powiedzieć, czy warownia ta została wzniesiona w konstrukcji drewniano-ziemnej, czy też od razu przystąpiono do stawiania murowanego zamku, a przede wszystkim jaka była jej faktyczna lokalizacja. Jeśli przyjąć założenie, że powstała po translokacji miasta i zbudowano ją w konstrukcji drewniano-ziemnej, to w związku z powołaniem komturstwa chełmińskiego i - jeżeli taka sytuacja miała miejsce - ustanowieniem tam zarazem siedziby komtura ziemi chełmińskiej, Krzyżacy mogli przystąpić do sukcesywnego zastępowania części drewnianych konstrukcjami murowanymi, co w tym czasie było dość powszechną praktyką (Wasik 2016a, s. 316-317).

${ }^{13}$ Zakon cysterek został sprowadzony do Chełmna w latach 60 . XIII wieku z inicjatywy mistrza krajowego Ludwika von Baldersheim. Tamtejszy klasztor funkcjonował do 1821 roku, kiedy to został wydany dekret o kasacie zakonu na obszarach państwa pruskiego (Domasłowski 1983, s. 7, 15). 


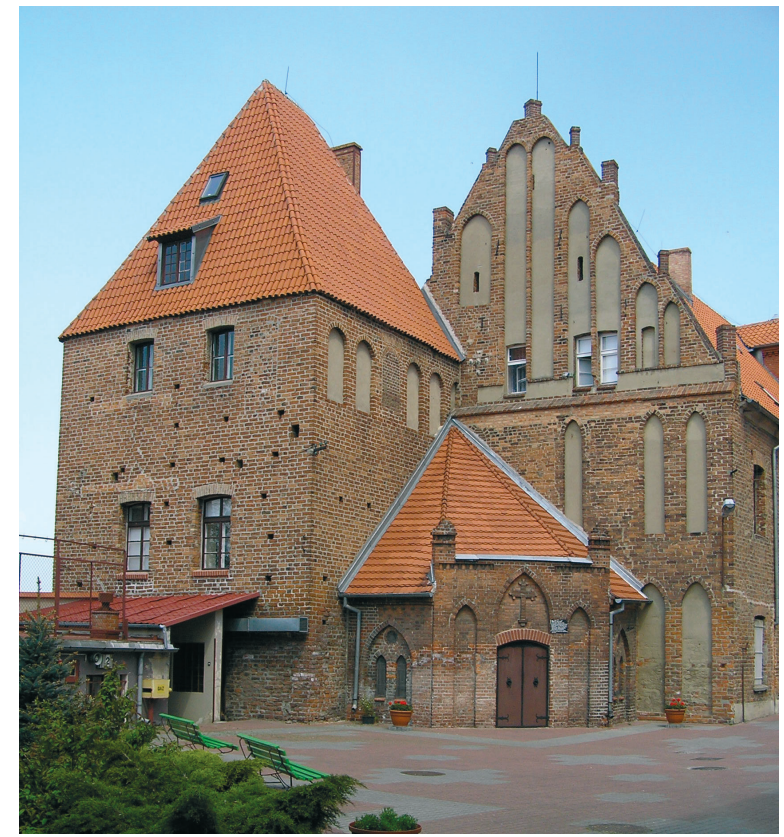

Ryc. 4. Chełmno. Wieża Mestwina i zachodni szczyt dawnego klasztoru cysterek (źródło: Wikipedia, https://pl.wikipedia.org/wiki/Plik:Chelmno_wieza_Mestwina.jpg)

Fig. 4. Chełmno. Mestwin's Tower and the western gable of the former Cistercian convent (source: Wikipedia, https://pl.wikipedia.org/wiki/Plik:Chelmno_wieza_Mestwina.jpg)

Po 1285 roku siedziba komtura ziemi chełmińskiej znalazła się w Lipienku, około $30 \mathrm{~km}$ na południowy wschód od Chełmna. Na taką ewentualność wskazuje wystawiony tam w marcu 1285 roku dokument potwierdzający nadanie wsi Morczyny biskupowi chełmińskiemu (Jóźwiak 2012, s. 48; Jóźwiak, Trupinda 2020, s. 136). Pierwsza wzmianka o jakiejś warowni w Lipienku pojawiła się w kronice Piotra z Dusburga, której autor podał, że dowodzeni przez Skumanda Prusowie wtargnęli do ziemi chełmińskiej (1277 rok) i podeszli pod kilka zamków („castra”), między innymi pod Lipienek (Piotr z Dusburga, s. 150-151). Istniejące wówczas założenie nie było jeszcze murowanym zamkiem, lecz drewniano-ziemną warownią, co potwierdziły przeprowadzone tam w 2018 roku badania archeologiczne ${ }^{14}$. Odsłonięto wówczas relikty wczesnośredniowiecznego grodu, który w drugiej połowie XIII wieku Krzyżacy odpowiednio zaadaptowali do swoich potrzeb poprzez podwyższenie wału (Bogusz i in. 2018; Wasik 2018). Niewielkie fragmenty późnośredniowiecznych naczyń ceramicznych nie dały możliwości dokładnego datowania tej konstrukcji, można jedynie ogólnie stwierdzić, że ma on XIII-wieczną chronologię (Wasik 2018).

${ }^{14}$ Badaniami w Lipienku kierował Bogusz Wasik. Realizowano je w ramach projektu pt. „Castra Terrae Culmensis - na rubieży chrześcijańskiego świata”. 
Trudno jednoznacznie określić datę rozpoczęcia budowy murowanego zamku w Lipienku. Prawdopodobnie w drugiej dekadzie XIV wieku posiadał on już co najmniej dwa murowane skrzydła, o czym można wnioskować na podstawie dokumentu z 1313 roku, w którym wymieniony jest dość liczny konwent komtura ziemi chełmińskiej (Jóźwiak, Trupinda 2020, s. 136). Przypuszczalnie zatem do budowy obiektu przystąpiono najpóźniej u schyłku XIII wieku, za czym przemawiałaby również regularność jego układu przestrzennego. Z pewnością do tego przyczyniło się w znacznym stopniu ustanowienie tam siedziby komtura ziemi chełmińskiej po 1285 roku (Jóźwiak 2012, s. 48; Wasik 2018). Zakończenie prac miało miejsce prawdopodobnie przed 1330 rokiem, kiedy to, zgodnie z przekazem Wiganda z Marburga, król Władysław Łokietek przystąpił do oblężenia zamku'15 (Wigand von Marburg, s. 148).

Warownię w Lipienku wzniesiono na półwyspie wcinającym się głęboko w wody jeziora (obecnie częściowo już wyschniętego), przez co można zaliczyć ją do zamków typu nizinnego, usytuowanych na półwyspach wysuniętych w jezioro (ryc. 5) (Wasik 2013, s. 56; 2016a, s. 282; 2018; Szczupak 2019). Założenie składało się z trzech części: zamku wysokiego, przedzamcza I oraz przedzamcza II (ryc. 6) (Wasik 2018). Zamek wysoki wzniesiono na planie czworoboku o wymiarach około $35 \times 38,5-39,7 \mathrm{~m}$. Jak zauważył B. Wasik, był on najmniejszy na obszarze ziemi chełmińskiej (Wasik 2018). Mimo, że zalicza się go do założeń regularnych, to jednak kurtyny nie zostały wymierzone precyzyjnie pod kątem prostym. Ta niedokładność może świadczyć o stopniowym kształtowaniu się regularnej formy architektonicznej, której geneza sięga lat 80 . XIII wieku (Wasik 2016a, s. 318; Wasik 2018). W tym miejscu należy jeszcze wspomnieć, że zamek w Lipienku wykazuje podobieństwo do obiektu w Papowie Biskupim (położonym około $9 \mathrm{~km}$ na północny wschód od Lipienka) pod względem wykorzystanego materiału budowlanego (w znacznej części były to kamienie narzutowe) oraz rzutu zamków wysokich (czworobocznych o zbliżonych wymiarach (Momot i in. 2014, s. 72; Torbus 2014, s. 72). Czy może to świadczyć o zbliżonym czasie rozpoczęcia budowy obu tych założeń? Do prac budowlanych w Papowie Biskupim najprawdopodobniej przystąpiono w latach 80. XIII wieku, do czego z pewnością przyczyniło się powołanie tamtejszego komturstwa na przełomie lat 70. i 80. XIII stulecia (Jóźwiak 1997, s. 130-132; Wasik 2016a, s. 274). W przypadku Lipienka, jak już wyżej wspomniano, data rozpoczęcia budowy zamku murowanego nie jest precyzyjnie określona. Można przypuszczać, że przystąpiono do niej po ustanowieniu tam siedziby komtura ziemi chełmińskiej, a więc po 1285 roku (Jóźwiak 2012, s. 48). Za ewentualnym starszeństwem założenia w Papowie mógłby również przemawiać brak wieży głównej, którą z kolei posia-

\footnotetext{
${ }^{15}$ Nieco inaczej to samo wydarzenie opisał w swojej kronice Piotr z Dusburga. Kronikarz podał, że wojska Władysława Łokietka podeszły pod zamek, ale nie oblegały go (Piotr z Dusburga, s. 240).
} 


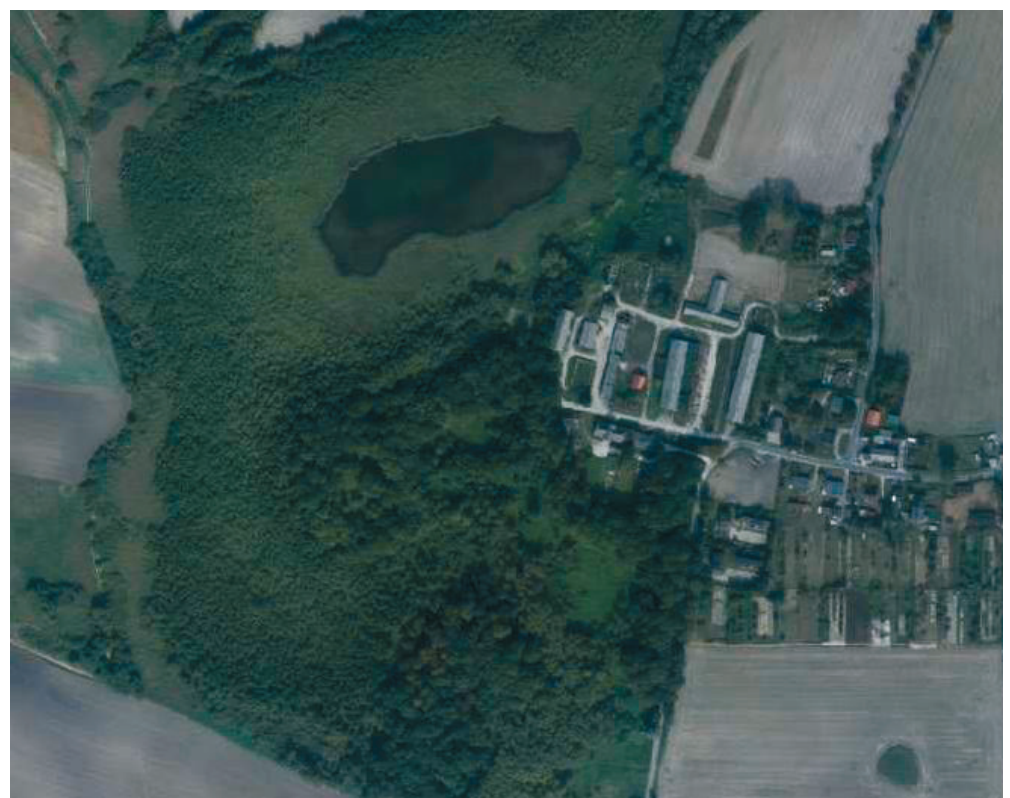

Ryc. 5. Lipienek, pow. Chełmno. Lokalizacja zamku w Lipienku (wg Google Map, oprac. D. Szczupak)

Fig. 5. Lipienek, Chełmno district. Location of the castle in Lipienek (after Google Map, edited by D. Szczupak)

dał Lipienek. Jednak, aby to starszeństwo potwierdzić, należałoby podjąć próbę określenia chronologii tej wieży zamku (por. niżej).

Układ przestrzenny zamku w Lipienku z pierwszych dekad XIV wieku jest trudny do odtworzenia ze względu na skąpe informacje zawarte w źródłach pisanych. Do podjęcia próby rekonstrukcji jego wyglądu mogą posłużyć spisy inwentarzowe z końca XIV i pierwszej połowy XV wieku oraz polska lustracja z 1565 roku (Wasik 2013, s. 57; 2016a, s. 282; Jóźwiak, Trupinda 2020, s. 138). Główne skrzydło zamkowe, z kaplicą na pierwszej kondygnacji, najprawdopodobniej znajdowało się w południowej części obwodu i z pewnością zostało wzniesione w pierwszej kolejności (Wasik 2016a, s. 282; 2018). Co ciekawe, żadne średniowieczne źródło pisane nie zawiera wzmianki o kaplicy zamkowej (Jóźwiak, Trupinda 2020, s. 138). Nie należy jednak zakładać, że takiego pomieszczenia tam nie było, gdyż jego obecność w zamku-klasztorze zakonu krzyżackiego była koniecznością. Poza tym w dokumencie z roku 1313 wzmiankowany był kapelan komtura ziemi chełmińskiej, co również może świadczyć o istnieniu tam kaplicy (Jóźwiak, Trupinda 2020, s. 138). W skrzydle zachodnim, w jego przyziemiu miały funkcjonować piekarnia oraz browar, które w pierwszych dekadach XIV wieku być może znajdowały się jeszcze w drewnianych budynkach. W przeciwieństwie do południowego, skrzydło zachodnie nie było podpiwniczone (Wasik 2013, s. 68; 2016a, s. 282). Trudna do określenia jest funkcja skrzy- 
deł północnego i wschodniego, gdzie być może znajdowała się zbrojownia lub słodownia (Jóźwiak, Trupinda 2020, s. 138). Skrzydła zamkowe posiadały również poddasza o charakterze magazynowym, w których przechowywano zboże (Wasik 2013, s. 68; Jóźwiak, Trupinda 2020, s. 138). W północno-wschodnim narożniku zamku wysokiego znajdowała się wieża główna, której forma architektoniczna - jak przypuszcza B. Wasik - zbliżona była do nieukończonej wieży w Golubiu, a co za tym idzie, nie była ona połączona ze skrzydłami zamkowymi $^{16}$ (Wasik 2016a, s. 282; 2018; Dołęgowska 2018). Jeśli chodzi o jej chronologię, należy wziąć pod uwagę założenia przyjęte między innymi przez Tomasza Torbusa, zdaniem którego wieże główne w obrębie zamków krzyżackich zaczęto wznosić dopiero od około roku 1300 (Torbus 2014, s. 354). Nie ma pewności, czy wieża w Lipienku została uwzględniona na etapie pierwotnego planowania zamku i czy wybudowano ją do roku 1335, kiedy nastąpiła likwidacja urzędu komtura ziemi chełmińskiej (Jóźwiak 2012, s. 134). Jej obecność z pewnością podkreślałaby monumentalność zamku i jednocześnie świadczyłaby o jego randze, na którą niewątpliwie wpływał fakt ustanowienia tam siedziby komtura ziemi chełmińskiej. Istnieje też możliwość, że wieża stała się częścią zamku nieco później, kiedy był on już siedzibą lipieneckiego wójta, czyli od lat 40. XIV wieku (Jóźwiak, Trupinda 2020, s. 136).

Zamek wysoki otoczony był parchamem w rzucie zbliżonym do nieregularnego wieloboku jego szerokość była zróżnicowana - od wschodu i północy wynosiła około $14 \mathrm{~m}$, natomiast od zachodu i południa - od 7,5 do $10 \mathrm{~m}$ (Wasik 2018). Na wschód od zamku wysokiego znajdowało się przedzamcze I, oddzielone głęboką fosą o szerokości 18-22 m, którą od południa zamykał załamany pod kątem mur (Wasik 2016a, s. 283; 2018). Przedzamcze wzniesiono na planie pięcioboku i otoczono je murem obronnym z wieżą bramną w jego wschodniej części (Wasik 2013, s. 57; 2016a, s. 283). Nie wiadomo jednak jak wyglądała jego zabudowa w czasach krzyżackich. Bogusz Wasik przypuszcza, że jeden z obiektów wymienionych w lustracji z 1565 roku, a mianowicie podpiwniczony budynek w północno-wschodnim narożniku, posiadał genezę średniowieczną (Wasik 2016a, s. 283). Od wschodu przedzamcze I było oddzielone fosą od rozległego obszaru o owalnym obrysie, który być może pełnił również funkcję przedzamcza, nie ma jednak pewności, czy istniało ono już w XIV wieku (Wasik 2016a, s. 284; 2018).

Zamek w Lipienku stanowił siedzibę komtura ziemi chełmińskiej do 1335 roku, kiedy to doszło do likwidacji tego urzędu (Jóźwiak 2012, s. 134). Od lat 40. XIV wieku w warowni rezydował już wójt, który podlegał bezpośrednio władzom centralnym w Malborku (Jóźwiak, Trupinda 2020, s. 136).

Podsumowując, precyzyjne wskazanie siedziby komtura ziemi chełmińskiej przed 1285 rokiem sprawia do dzisiaj spore trudności. Nikłe wzmianki w źródłach

${ }^{16}$ Pozostałości zachodniej ściany wieży odsłonięto podczas badań w 2018 roku. 


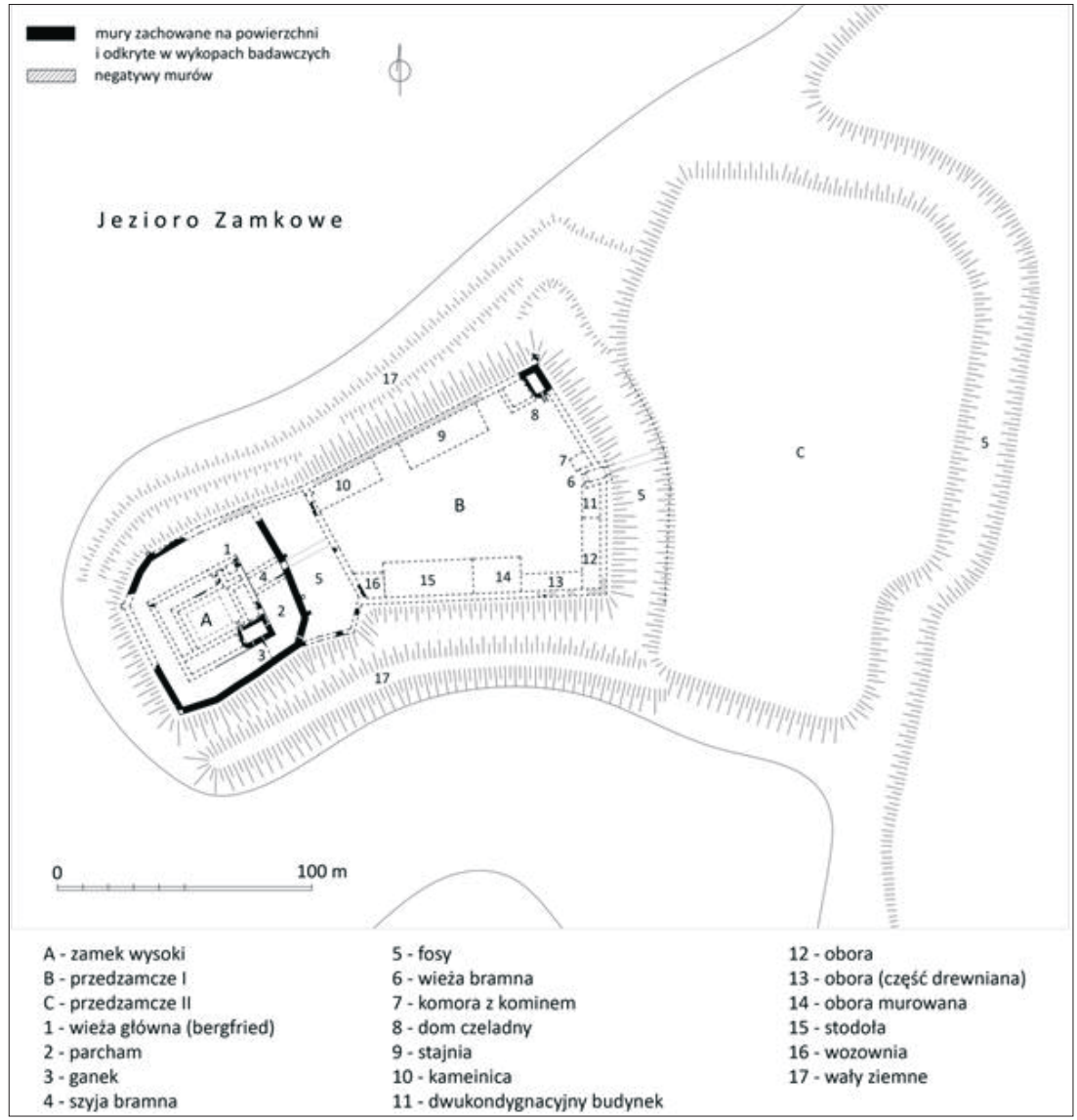

Ryc. 6. Lipienek, pow. Chełmno. Rekonstrukcja rozplanowania zamku w połowie XVI wieku (oprac. B. Wasik)

Fig. 6. Lipienek, Chełmno district. Reconstruction of the layout of the castle in the mid- $16^{\text {th }}$ century (edited by B. Wasik)

pisanych pozwalają jedynie na formułowanie przypuszczeń. Badacze wskazują zatem trzy potencjalne lokalizacje: Starogród, Potterberg i Chełmno. Przyjmowanie Starogrodu jako siedziby komtura ziemi chełmińskiej mogłoby wynikać zarówno z faktu, że prawdopodobnie rezydował tam jego poprzednik - zarządca (provisor), jak i z pierwszoplanowej rangi miejsca, do której przyczyniło się zdeponowanie tam głowy św. Barbary, zdobytej w Sartowicach w 1242 roku. Mimo, że urzędnik ten w latach 1310-1320 przejął czasowe zwierzchnictwo nad obszarem podległym komturstwu starogrodzkiemu, jest rzeczą wątpliwą, aby rezydował wówczas w Starogrodzie. Badania archeologiczne z 2017 roku przyniosły nowe, interesujące odkrycia na temat tamtejszego założenia zamkowego. Przede wszystkim potwierdzono fakt istnienia drewniano-ziemnej warowni, poprzedzającej murowany zamek, a analiza nawarstwień i reliktów architektonicznych 
umożliwiła podjęcie próby rekonstrukcji formy architektonicznej założenia od XIII do XV wieku.

Warownia Potterberg od schyłku lat 40. do początku lat 80. XIII wieku mogła stanowić siedzibę komtura ziemi chełmińskiej. Wzniesiono ją około 1246/1247 roku, a na miejsce pod jej budowę prawdopodobnie wybrano Górę św. Wawrzyńca w Kałdusie. Być może wspomniany urzędnik rezydował tam także po 1251 roku, kiedy to powołano urząd komtura starogrodzkiego. W takim przypadku należałoby przyjąć, że do tego czasu jego siedzibą był Starogród, jednak ze względu na brak wzmianek w średniowiecznych źródłach pisanych pozostaje jedynie snuć przypuszczenia na ten temat. Jeśli komtur ziemi chełmińskiej rezydował w warowni Potterberg od schyłku lat 40. do początku lat 80 . XIII wieku, to wówczas prawdopodobnie przystąpiono do przekształcania drewniano-ziemnego założenia $\mathrm{w}$ murowany zamek. $\mathrm{W}$ trakcie badań archeologicznych $\mathrm{z}$ lat 60. i 70. XX wieku, prowadzonych na Górze św. Wawrzyńca w Kałdusie, nie odkryto jednak żadnych murowanych reliktów, natrafiono wówczas jedynie na pozostałości ziemnego wału z trzema rzędami palisady w jego koronie. Nie pozyskano też żadnych danych umożliwiających podjęcie próby rekonstrukcji zabudowy wewnętrznej tej drewniano-ziemnej warowni. W przypadku miasta Chełmna, w którym również mogła znajdować się siedziba komtura ziemi chełmińskiej przed 1285 rokiem, sytuacja jest równie skomplikowana. Źródła pisane wskazują jedynie na to, że przed 1278 rokiem ustanowiono urząd komtura rezydującego w Chełmnie, który jednak zniesiono przed 1285 rokiem. Jak można zauważyć, data likwidacji tego urzędu jest zbieżna z pojawieniem się siedziby komturów ziemi chełmińskiej w Lipienku. Nie jest to jednoznaczny dowód na rezydowanie w Chełmnie komtura ziemi chełmińskiej (wówczas trzeba założyć, że w Chełmnie rezydował komtur nowego Chełmna i komtur ziemi chełmińskiej), ale może to stanowić wskazówkę do ewentualnych dalszych badań nad lokalizacją siedziby tego urzędnika przed 1285 rokiem. Sytuacja jest również skomplikowana w przypadku tamtejszej warowni krzyżackiej, gdyż badacze nie dysponują zarówno źródłami archeologicznymi, jak i pisanymi, które mogłyby dostarczyć informacji na temat jej lokalizacji oraz formy architektonicznej. Istnieje teoria, że należałoby jej szukać na obszarze zespołu klasztornego Sióstr Miłosierdzia, a jej pozostałością miałaby być tzw. wieża Mestwina. Została ona sformułowana na podstawie przesłanki mówiącej o tym, że w XIV wieku wieża zamkowa (wspomniana już wieża Mestwina) przeszła w posiadanie cysterek.

Jeśli chodzi o lokalizację siedziby komtura ziemi chełmińskiej po 1285 roku, to badacze nie mają już wątpliwości, że znajdowała się ona w Lipienku. Przeprowadzone tam w 2018 roku badania archeologiczne potwierdziły istnienie drewniano-ziemnej warowni w drugiej połowie XIII wieku oraz umożliwiły bardziej dokładne odtworzenie wyglądu murowanego zamku. Jedynie więc w przypadku Chełmna stan badań historycznych i archeologicznych jest niewystarczający 
i wymagałby istotnego poszerzenia. Dobrym rozwiązaniem byłoby przeprowadzenie na obszarze tamtejszego zespołu klasztornego Sióstr Miłosierdzia nieinwazyjnych badań geofizycznych, powszechnie stosowanych we współczesnej archeologii, na przykład pomiarów georadarowych. Za ich pomocą możliwe byłoby zlokalizowanie ewentualnych murowanych reliktów tamtejszego zamku krzyżackiego.

Bibliografia

Wykaz skrótów

AHP

- Archaeologia Historica Polona, Toruń

Państwo zakonu krzyżackiego

- Państwo zakonu krzyżackiego w Prusach. Władza i społeczeństwo, red. M. Biskup, R. Czaja, Warszawa

\section{Źródła}

Piotr z Dusburga

- Piotr z Dusburga. Kronika ziemi pruskiej, thum. S. Wyszomirski, komentarze J. Wenta, Toruń 2004.

Przywilej chetmiński

- Przywilej chetmiński 1233 i 1251, wyd. K. Zielińska-Melkowska, Toruń 1986.

Wigand von Marburg

- Wigand von Marburg. Nowa kronika pruska, oprac. S. Zonenberg, K. Kwiatkowski, Toruń 2017.

\section{Literatura}

Antkowiak W., Lamparski P., 1999, Zamki i strażnice krzyżackie ziemi chetmińskiej (historia, plany, tajemnice), Toruń.

Bogusz A., Roman A., Wasik B., 2018, Wykop 1, [w:] Sprawozdanie z badań archeologiczno-architektonicznych zamku w Lipienku (stan. nr 1) przeprowadzonych w 2018 roku, maszynopis w Instytucie Archeologii UMK, Toruń.

Chudziak W., 2014, Dtugi wiek XIII w Chetmnie, AHP, t. 22, s. 55-67.

Chudziak W., Bojarski J., 2015, Chetmno i Toruń. Poczatki miast na ziemi chetmińskiej, AHP, t. 23, s. 83-105.

Czaja R., 2008, Urbanizacja kraju, [w:] Państwo zakonu krzyżackiego, s. 177-199.

Dołęgowska M., 2018, Wykop 5, [w:] Sprawozdanie z badań archeologiczno-architektonicznych zamku w Lipienku (stan. nr 1) przeprowadzonych w 2018 roku, maszynopis w Instytucie Archeologii UMK, Torun. 
Domasłowski J., 1983, Kościót i dawny klasztor Cysterek w Chetmnie, WarszawaPoznań-Toruń.

Dorna M., 2004, Bracia zakonu krzyżackiego w Prusach w latach 1228-1309, Poznań.

Dygo M., 2008a, Początki i budowa władztwa zakonu krzyżackiego (1226-1309), [w:] Państwo zakonu krzyżackiego, s. 53-78.

Dygo M., 2008b, Ekspansja terytorialna i władztwo terytorialne (1249-1309), [w:] Państwo zakonu krzyżackiego, s. 79-104.

Jähnig B., 2013, Dostojnicy zakonu krzyżackiego w Prusach, [w:] Zakon krzyżacki $w$ Prusach i Inflantach. Podziały administracyjne i kościelne w XIII-XVI wie$k u$, red. R. Czaja, A. Radzimiński, Toruń, s. 279-329.

Jóźwiak S., 1996, Translokacje Chetmna a powstanie komturstw staro- $i$ nowochetmińskiego, [w:] Studia nad dziejami miast i mieszczaństwa w średniowieczu, red. R. Czaja, J. Tandecki, Toruń, s. 83-94.

Jóźwiak S., 1997, Powstanie i rozwój struktury administracyjno-terytorialnej zakonu krzyżackiego na Kujawach $i$ w ziemi chetmińskiej w latach 1246-1343, Toruń.

Jóźwiak S., 1998, Rezygnacje z kariery wysokich hierarchów zakonu krzyżackiego w Prusach w XIV wieku, Komunikaty Mazursko-Warmińskie, nr 1/1998, s. $21-36$.

Jóźwiak S., 2000, (rec.) Die Einrichtung von Verwaltungsstrukturen in Preußen durch den Deutschen Orden bis zur Mitte des 13. Jahrhunderts, M. Löwener, Wiesbaden 1998, Komunikaty Mazursko-Warmińskie, nr 1/2000, s. 113-117.

Jóźwiak S., 2007, Liczebność konwentów zakonu krzyżackiego w Prusach w pierwszej połowie XV wieku, ZH, t. 72, z. 1, s. 7-22.

Jóźwiak S., 2008, Podziały administracyjne, [w:] Państwo zakonu krzyżackiego, s. $132-137$.

Jóźwiak S., 2012, Centralne $i$ terytorialne organy władzy zakonu krzyżackiego w Prusach w latach 1228-1410: rozwój, przekształcenia, kompetencje, Torun.

Jóźwiak S., Trupinda J., 2012, Krzyżackie zamki komturskie w Prusach. Topografia i układ przestrzenny na podstawie średniowiecznych źródel pisanych, Toruń.

Jóźwiak S., Trupinda J., 2020, Zamki krzyżackie w świetle średniowiecznych źródet pisanych, [w:] Castra Terrae Culmensis. Na rubieży chrześcijańskiego świata, t. 1, red. M. Wiewióra, Toruń s. 132-151, 167-168.

Kola A., Matuszewska-Kola W., 1971, Kałdus, pow. Chetmno, Informator Archeologiczny. Badania rok 1970, Warszawa, s. 171-172.

Löwener M., 1998, Die Einrichtung von Verwaltungsstrukturen in Preußen durch den Deutschen Orden bis zur Mitte des 13. Jahrhunderts, Wiesbaden.

Momot A., Wasik B., Wiewióra M., 2014, Zamek krzyżacki w Papowie Biskupim. Nowe odkrycia i nowe interpretacje, Rocznik Grudziądzki, t. 22, s. 65-97.

Mroczko T., 1974, Ruch budowlany na ziemi chetmińskiej w XIII i XIV wieku, [w:] Sztuka i ideologia XIII wieku. Materiały Sympozjum Komitetu Nauk o Sztuce 
Polskiej Akademii Nauk. Warszawa 5 i 6 IV 1971, red. P. Skubiszewski, Warszawa-Wrocław, s. 281-332.

Oliński P., 1998, Motywy chrystologiczne na pieczęciach urzędników krzyżackich ziemi chetmińskiej, Rocznik Grudziądzki, t. 13, s. 9-20.

Poliński D., 2005, Gród czy zamek? Z badań nad najwcześniejszymi krzyżackimi obiektami obronnymi w ziemi chetmińskiej, AHP, t. 15/1, s. 181-196.

Powierski J., 1972, Hugo Butyr. Fragment stosunków polsko-niderlandzkich, Zapiski Historyczne, t. 37, z. 2, s. 9-43.

Szczupak D., 2019, Topografia i lokalizacja zamków krzyżackich na ziemi chełmińskiej w świetle badań archeologicznych, historycznych i geograficznych, maszynopis pracy licencjackiej w Instytucie Archeologii UMK, Toruń.

Sprawozdanie z badań, 2018, Sprawozdanie z badań z badań archeologicznych przeprowadzonych na terenie pierwszego miasta lokacyjnego Chełmna w Starogrodzie w 2018 roku, red. B. Wasik, maszynopis w Instytucie Archeologii UMK, Toruń.

Steinbrecht C., 1888, Die Baukunst des Deutschen Ritterordens in Preussen, t. 2: Preussen zur Zeit der Landmeister, Berlin.

Tandecki J., 2008, Zakon krzyżacki, [w:] Państwo zakonu krzyżackiego, s. 405-419.

Torbus T., 2014, Zamki konwentualne państwa krzyżackiego w Prusach, Gdańsk.

Wasik B., 2013, Zamek w Lipienku na ziemi chetmińskiej, Rocznik Grudziądzki, t. 21, s. $51-74$.

Wasik B., 2016a, Budownictwo zamkowe na ziemi chetmińskiej od XIII do XV wieku, Toruń.

Wasik B., 2016b, Początki krzyżackich zamków na ziemi chetmińskiej. Pierwsze warownie i obiekty murowane, AHP, t. 24, s. 233-260.

Wasik B., 2017a, Układ przestrzenny i fazy funkcjonowania zamku, [w:] Sprawozdanie z badań archeologiczno-architektonicznych zamku w Starogrodzie (stan. nr 1) przeprowadzonych w 2017 roku, maszynopis w Instytucie Archeologii UMK, Toruń.

Wasik B., 2017b, Wstęp, [w:] Sprawozdanie z badań archeologiczno-architektonicznych zamku w Starogrodzie (stan. nr 1) przeprowadzonych w 2017 roku, maszynopis w Instytucie Archeologii UMK, Toruń.

Wasik B., 2018, Układ przestrzenny i fazy funkcjonowania zamku, [w:] Sprawozdanie z badań archeologiczno-architektonicznych w Lipienku (stan. nr 1) przeprowadzonych w 2018 roku, maszynopis w Instytucie Archeologii UMK, Toruń.

Wasik B., Cackowski K., 2017, Wykop 3, [w:] Sprawozdanie z badań archeologiczno-architektonicznych zamku w Starogrodzie (stan. nr 1) przeprowadzonych w 2017 roku, maszynopis w Instytucie Archeologii UMK, Toruń.

Wiewióra M., 2016, Gród i zamek w państwie krzyżackim - miejsce tradycji czy tradycja miejsca?, AHP, t. 24, s. 195-231. 


\section{THE ISSUE OF THE LOCATION OF THE SEAT (MONASTERY) OF THE COMMANDERS OF THE CHEŁMNO LAND IN THE $13^{\mathrm{TH}}$ CENTURY-FIRST DECADES OF THE $14^{\mathrm{TH}}$ CENTURY}

Keywords: commander of the Chełmno Land, Starogród, Potterberg, Chełmno, Lipienek, archaeology, history, castle, fortress, Teutonic Order.

\section{Summary}

The author of this article attempts to indicate the location and to determine the earliest seat of komtur of the Chełmno Land in the $13^{\text {th }}$ - the first decades of the $14^{\text {th }}$ century. The considerations carried out in it were based on the analysis of historical sources, re-verification of previous views and the results of archaeological researches.

Four locations were discussed in which researchers are looking for the residence of komtur of the Chełmno Land. When trying to reconstruct the architectural form of those assumptions, the results of archaeological researches conducted in 2016-2019 as part of the project 'Castra Terrae Culmensis - on the edge of the Christian world', managed by Marcin Wiewióra (Institute of Archaeology of the Nicolaus Copernicus University in Toruń) turned out to be particularly important. They enabled not only the reconstruction of spatial systems and the chronology of these objects, but also verified the existence of wooden and earthen strongholds preceding the masonry castles.

The analyzes conducted by the author shows the complexity of the research problem, which is the issue of the location of the seats of the mentioned Teutonic officials, and are to contribute to further researches on this issue.

Translated by Dominika Szczupak 